\title{
The impact of harbour sludge disposal on benthic macrofauna communities in the Weser estuary
}

Received: 2 December 2002 / Revised: 7 April 2004 / Accepted: 15 April 2004 / Published online: 19 May 2004

(C) Springer-Verlag and AWI 2004

\begin{abstract}
During an open-water disposal of about $710,000 \mathrm{~m}^{3}$ of harbour sludge in the polyhaline zone of the Weser estuary, Germany, a monitoring programme was carried out to investigate the impact on benthic invertebrates. The macrofaunal communities of four sites within the disposal area and five sites in a reference area were compared after discharge. The location and extent of the potentially affected area were inferred from a morphodynamic computer model (TIMOR 3; Zanke 1998). Disposal effects were analysed by comparing species numbers, densities, diversity and faunal similarity using multivariate methods. A loss of diversity and a decline in the abundance of several species in the disposal area were measured. The species number was reduced up to $50 \%$ and important habitat structures were absent from the disposal area. Several benthic species were affected by the disposal. The importance of species such as Mytilus edulis (Mollusca) and Lanice conchilega (Polychaeta) for the diversity of the community, and the sensitivity of these species to sediment discharge are analysed. The difficulties of separating dumping effects from natural variation in a dynamic estuarine channel system are discussed.
\end{abstract}

Keywords Harbour sludge disposal - Dumping effects · Impact assessment · Benthic invertebrates - Weser estuary

Communicated by H.-D. Franke

J. Witt $(\bullet)$

Küstenökologische Forschungsgesellschaft mbH (KÜFOG),

Alte Deichstr. 39, 27612 Loxstedt-Ueterlande, Germany

e-mail: jan.witt@kuefog.de

Tel.: +49-4740-1071

Fax: +49-4740-1027

J. Witt · A. Schroeder · R. Knust - W. E. Arntz Alfred Wegener Institute for Polar and Marine Research (AWI), Columbusstraße, 27515 Bremerhaven, Germany

\section{Introduction}

The effects of sediment disposal on macrofaunal communities in open waters have been investigated by several authors (Rosenberg 1977a, 1977b; Wildish and Thomas 1985; Mühlenhardt-Siegel 1988, 1990; Essink et al. 1992). The impact on the benthic communities varies from minimal to severe, depending on the amount and type of material and the modus of discharge. The formation of deposit layers, changes in sediment composition, an increase in turbidity and chemical changes in the water column are the main stress factors to invertebrates after a discharge (Essink 1995, 1996; Krost 1996). The high variability of benthic communities in dynamic systems such as estuaries makes it difficult to differentiate between natural variability and changes induced by humans (Wildish and Thomas 1985). A reliable impact assessment of sediment disposal in open waters and a standardization of methods is therefore an international scientific objective (BFG 1992, 1999; PIANC 1998).

For the maintenance of the harbours of Bremerhaven, Germany, dredging is necessary at regular intervals. The sedimentation rate in the harbours varies between 0.3 and $1.6 \mathrm{~m} / \mathrm{a}$ due to the high suspension load of the river Weser and the sedimentation conditions in the semi-enclosed harbours (Woltering 1997). About $550,000 \mathrm{~m}^{3}$ of muddy sediments from the harbours have been dumped in the polyhaline zone of the Weser estuary each year. This investigation was carried out on behalf of the Harbour Administration of Bremen (Bremenports $\mathrm{GmbH}$, formerly $\mathrm{HBH}$ ) in order to assess the effects of harbour sludge disposal on the benthic macrofaunal community.

\section{Methods}

The Weser estuary is funnel-shaped, with a wide opening towards the North Sea. Due to the tidal amplitude and the volume of freshwater outflow, it is considered partially mixed (Wellershaus 1981; McLusky 1989). The main tidal channel of the Weser was built and is maintained as a major shipping lane with a large number of cargo ships using it regularly. The survey area is located 


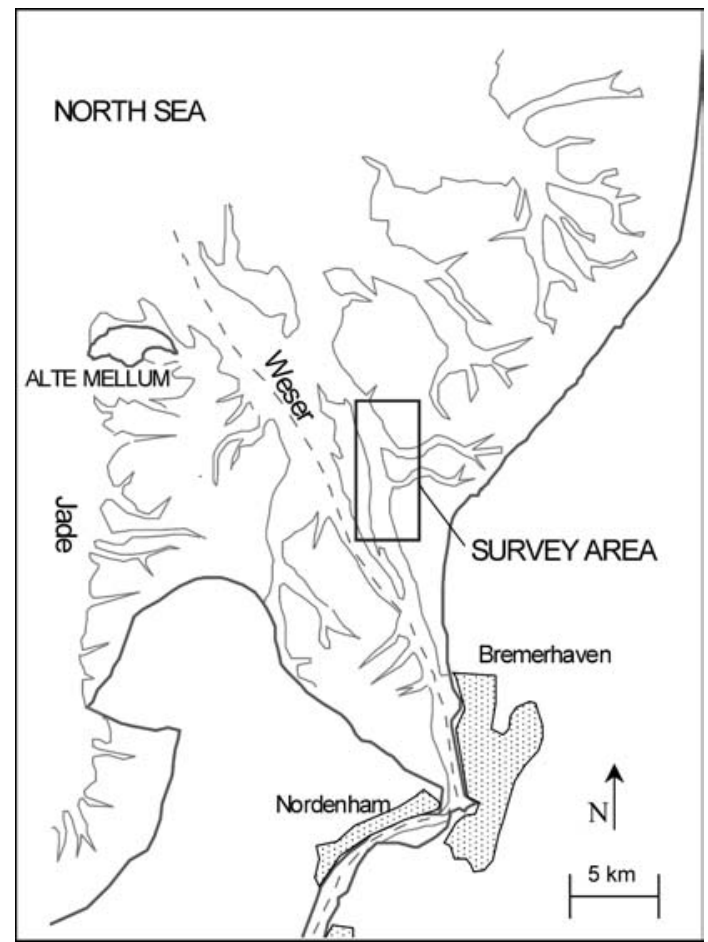

Fig. 1 The Weser estuary with the survey area Wurster Arm (dashed line indicates shipping lane)

in a neighbouring side channel called the Wurster Arm, which is used by smaller vessels, many of which are private, and for fishery purposes (Fig. 1). The disposal area, in the centre of this channel, has been used for sediment discharge since the 1960s. It has a water depth of $16 \mathrm{~m}$, while the average depth of the channel is around $8 \mathrm{~m}$. In the study area there is a strong tidal current of up to $1.5 \mathrm{~m} / \mathrm{s}$ (KÜFOG 1998). The salinity varies from 17-30 PSU. The survey area is therefore a polyhaline brackish-water zone (Remane 1958; McLusky 1989).

Samples were collected at nine sites (Fig. 2). The stations within the dumping area (I-IV) were in the centre of the channel, about $100 \mathrm{~m}$ apart from each other. The reference stations VII and VIII were located south of the disposal area, the reference station IX north of it. The stations V and VI were located close to the disposal area, towards the intertidal flats, in shallower water (Fig. 2).

The distinction between the potentially affected area and the reference area was made according to a morphodynamic computer model (TIMOR 3; Zanke 1998). This model was based on field data such as water depth, currents, tidal water exchange, turbidity and sediment composition. This model predicted an increase in turbidity caused by the disposal, the spatial distribution of sediment fractions, and the height and duration of the sediment layer from the time of disposal. The area of main impact was defined as the area with an additional sediment layer of $10 \mathrm{~mm}$ or more for a minimum of 25 days/year and with an increased turbidity of more than $35 \%$ above the natural rate (Fig. 2). Natural turbidity in the survey area varies with tides from $10-100 \mathrm{mg} / \mathrm{l}$ of suspended matter (Zanke 1998).

The periods of dumping and sampling are shown in Fig. 3. Samples were collected 2-3 weeks after each disposal period. The recovery of the benthic community from disposal effects was investigated in August 1999; results will be presented elsewhere. The amount of discharged sediment varied from $800-383,000 \mathrm{~m}^{3}$. The material from the harbours was mainly soft silt sediment which contained a high percentage of organic matter. The area has been used as a disposal site for many years. Therefore, in the absence of any pre-dumping data, the biological situation before dumping began is unknown. Sampling at each site included three replicates

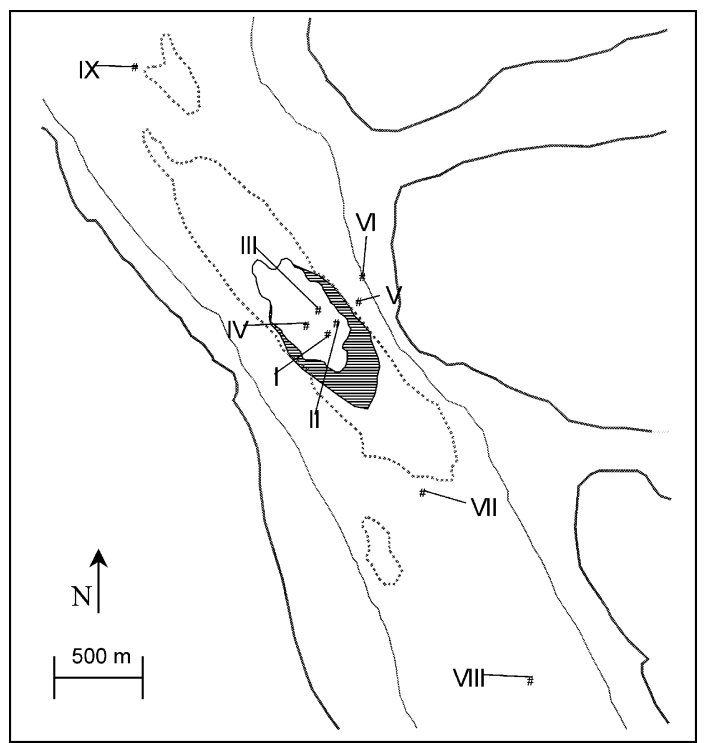

Fig. 2 Location of sampling sites in the survey area (white region in centre is the area of maximum sediment deposit, black-striped region is the area of maximum suspension increase, based on a sedimentation model of Zanke (1998)

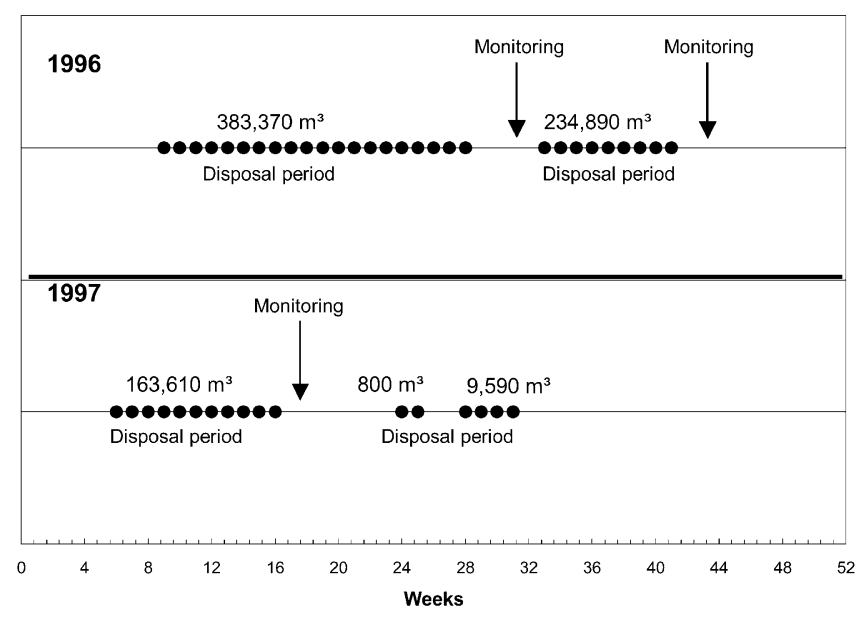

Fig. 3 Time schedule of dumping periods and monitoring surveys (amount of discharged material in $\mathrm{m}^{3}$ )

of van Veen grabs $\left(0.1 \mathrm{~m}^{2}\right)$ and one dredge trawl (1 m wide, 5-mm mesh size). The sediment of the van Veen grab was classified, and washed through a sieve with a 1-mm mesh size. The residue was stored in cooled seawater containers; it was then sorted and classified in the laboratory the next day, or it was stored in $80 \%$ ethanol (crustaceans) or buffered 5\% formalin (polychaetes) for later identification. An additional grab sample was taken at each site for grain-size analysis and for measuring organic content by loss of weight on ignition (Buchanan 1984).

The dredging direction followed tidal currents, which ensured a steady contact with the bottom. Part of the catch was sorted and classified on board, whilst the remainder was processed as mentioned above. As far as possible, macrofaunal organisms were identified to species level. For faunal analysis, a total of 81 grab and 27 dredge samples were taken. The vessel Hol Deep of the Harbour Administration of Bremen (Bremenports) was used for the survey. 
Table 1 Sediment parameters for the disposal and reference areas

\begin{tabular}{lllcc}
\hline Survey & Sediment parameter & Significance $^{\mathrm{a}}$ & $\begin{array}{c}\text { Disposal area } \\
\text { (stations I-IV) }\end{array}$ & $\begin{array}{l}\text { Reference area } \\
\text { (stations VI-IX) }\end{array}$ \\
\hline August 1996, $n=4$ & Silt (\%) & 21.8 & 17.7 \\
& Organic matter (\%) & 5.8 & 3.8 \\
October 1996, $n=4$ & Median grain size (mm) & $* *$ & 0.08 & 0.09 \\
& Silt (\%) & $* *$ & 58.0 & 11.50 \\
& Organic matter (\%) & 10.0 & 3.3 \\
April 1997, $n=4$ & Median grain size (mm) & $* *$ & 0.06 & 0.1 \\
& Silt (\%) & $* *$ & 43.7 & 2.7 \\
& Organic matter (\%) & $* *$ & 9.5 & 1.0 \\
Overall, $n=12$ & Median grain size (mm) & $* *$ & 0.09 & 8.10 \\
& Silt (\%) & $* *$ & 41.1 & 2.6 \\
& Organic matter $(\%)$ & 8.1 & 0.10 \\
\hline
\end{tabular}

${ }^{\text {a }}$ Mann-Whitney test; $* P<0.1, * * P<0.05, * * * P<0.01$
The analysis of the endobenthic data (grab samples) was based on endobenthic and sessile epibenthic species only. Epibenthic data (dredge samples) were handled separately. Pelagic species such as Pleurobrachia spp., Bougainvillia spp. and Sagitta spp. were not considered in the analyses. Because station $\mathrm{V}$ was located at the boundary between the disposal and reference area, it was not used for direct comparisons (see Fig. 2).

Community structure was analysed using univariate methods, such as comparisons of species density and community diversity, and multivariate techniques (faunal similarity). Ecological information and feeding behaviour were obtained from the literature, such as Hayward and Ryland (1990), Barnes (1994) and HartmannSchröder (1996). The diversity indices used included Shannon's diversity index $\left(H^{\prime}\right.$, based on $\left.\log 2\right)$, and measurements of evenness $\left(J^{\prime}\right)$ and species richness $(S R)$, as described by Pielou (1975) and Margalef (1958). Differences were analysed using the MannWhitney U-test. For statistical analyses of faunal data, the software package PRIMER, PML (v. 5) was used (Clarke and Warwick 1994; Clarke and Gorley 2001). Non-metric, multi-dimensional scaling (MDS) was used to identify patterns in the community structure (Kruskal and Wish 1978). Characteristic species, which contribute most to the similarity of the station groups, were identified using the SIMPER (similarity percentage) analysing tool of the PRIMER software. Data was transformed to the fourth root to minimise the influence of dominant species. Similarities were calculated using the Bray-Curtis coefficient (Boesch 1977).

\section{Results}

\section{Sediments}

Sediments at the dumping site (stations I-IV) and the reference area (stations VI-IX) differed at all times. Sediments in the disposal area had a higher percentage of silt and organic matter, and a lower median particle size than those of the reference area (Table 1, Fig. 4). The differences between the dumping site and the reference area were small in August 1996, but large in October 1996 and April 1997. The proportion of silt correlated positively with the percentage of organic matter. In April 1997, the percentage of silt was low in the reference area, with a small variation between the stations. High variation in sediment composition over time was noticed at station IV. The reference stations showed more consistent sediment conditions, with a higher proportion of fine sand. Station V, which was located close to the disposal site, had stable sediment conditions with over
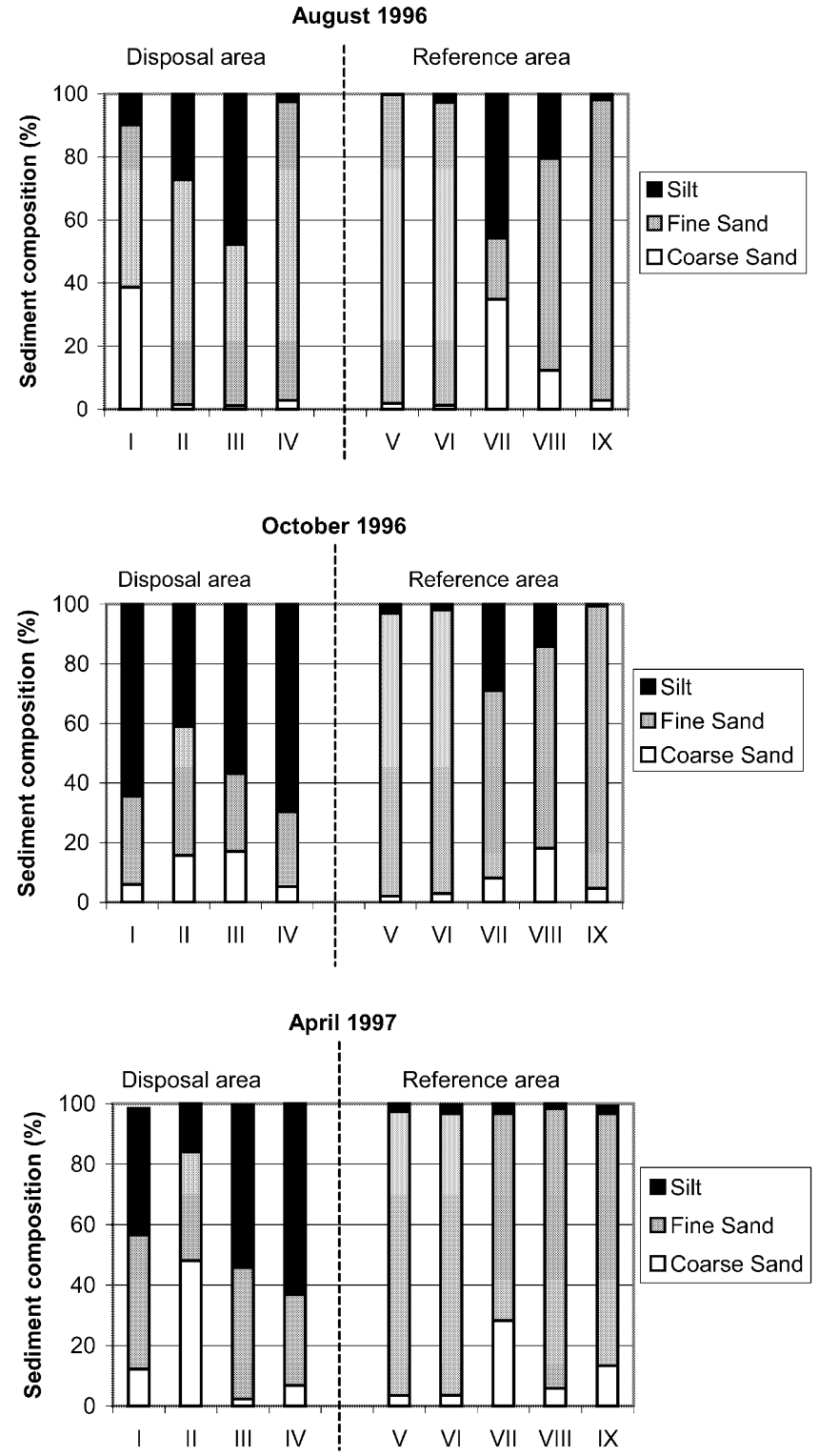

Fig. 4 Results of sediment analysis (\% dry weight) in the disposal area (stations I-IV) and the reference area (stations V-IX) 
Table 2 Numbers of species and individuals (mean $\pm \mathrm{SD})$ and community indices (mean) from grab samples in the disposal $(n=12)$ and the reference $(n=12)$ areas (endobenthic and sessile epibenthic species only)

\begin{tabular}{|c|c|c|c|c|c|}
\hline & \multirow[t]{2}{*}{ Signficance $^{\mathrm{a}}$} & \multicolumn{2}{|c|}{$\begin{array}{l}\text { Disposal area } \\
\text { (stations I-IV) }\end{array}$} & \multicolumn{2}{|c|}{$\begin{array}{l}\text { Reference area } \\
\text { (stations VI-IX) }\end{array}$} \\
\hline & & Mean & $\pm \mathrm{SD}$ & Mean & $\pm \mathrm{SD}$ \\
\hline \multicolumn{6}{|l|}{ Species per site } \\
\hline Total & $* *$ & 5.7 & 4.4 & 10.6 & 6.8 \\
\hline Endobenthic only & $* * *$ & 3.8 & 2.3 & 7.8 & 5.2 \\
\hline Cnidaria & & 0.7 & 1.1 & 0.8 & 1.3 \\
\hline Crustacea & $* * *$ & 0.7 & 1.0 & 2.0 & 1.3 \\
\hline Polychaeta & $* *$ & 2.5 & 1.3 & 5.0 & 3.6 \\
\hline Mollusca & $*$ & 1.4 & 1.2 & 2.3 & 1.1 \\
\hline \multicolumn{6}{|l|}{ Individuals per $\mathrm{m}^{2}$} \\
\hline Total & $*$ & 172.8 & 224.6 & 486.5 & 821.1 \\
\hline Endobenthic only & $* *$ & 112.6 & 142.5 & 381.8 & 682.0 \\
\hline Crustacea & $* *$ & 6.8 & 15.2 & 85.5 & 166.9 \\
\hline Polychaeta & & 96.3 & 128.8 & 260.9 & 512.5 \\
\hline Mollusca & $* *$ & 53.8 & 130.4 & 118.2 & 175.7 \\
\hline \multicolumn{6}{|l|}{ Community indices } \\
\hline Diversity & $*$ & 0.85 & - & 1.15 & - \\
\hline Species richness & $* *$ & 0.68 & - & 1.21 & - \\
\hline Evenness & & 0.68 & - & 0.69 & - \\
\hline
\end{tabular}

${ }^{\text {a }}$ Mann-Whitney test; $* P<0.1, * * P<0.05, * * * P<0.01$
90\% fine sand and no obvious silt sedimentation from the disposal.

Endobenthic macrofauna (grab sample data)

A total of 31 benthic species (5.7 per station) were collected by grab in the disposal area, compared to 51 species (10.6 per station) in the reference area. An average of 172.8 individuals per $\mathrm{m}^{2}$ were found in the disposal area, and 486.5 individuals per $\mathrm{m}^{2}$ in the reference area. Table 2 gives species numbers, individual numbers and community indices of the grab samples (endobenthic and sessile epibenthic species only) from the disposal area (stations I-IV) and the reference area (stations VI-IX).

The average number of 3.8 endobenthic species per station in the disposal area was significantly lower than the 7.8 species per station in the reference area $(P<0.01$, Table 2). A maximum of 22 species was found at station VII in August 1996. The average number of 112.6 individuals per $\mathrm{m}^{2}$ in the disposal area was significantly lower $(P<0.05)$ than the 381.1 individuals per $\mathrm{m}^{2}$ in the reference area. The average diversity $\left(H^{\prime}\right)$ was significantly lower in the disposal area $(0.85, P<0.1)$ than in the reference area (1.15). The species richness of 0.68 in the disposal area was significantly lower than the value of 1.21 at the reference sites $(P<0.05$, Table 2$)$.

There was a clear seasonal influence (Fig. 5): The number of species and the number of individuals were high in August and low in October and April. The highest diversity was found in August 1996, the lowest in October 1996. The differences in diversity $\left(H^{\prime}\right)$ between disposal and reference sites were high in October (Fig. 5). All data showed a clear difference between disposal and reference area. The evenness $\left(J^{\prime}\right)$ had a maximum of 0.75 in the disposal area in October and 0.82 in the reference area in April 1997.
Comparing both areas at a higher taxonomic level, there were significantly lower species numbers of crustaceans, polychaetes and molluscs in the disposal area (Table 2). The abundance of crustaceans $(P<0.05)$ and molluscs $(P<0.025)$ at the dumping sites was significantly lower than in the reference area. Dominant species in the disposal area were Heteromastus filiformis with $47 \%$ of all individuals, followed by Marenzelleria viridis (13\%) and Macoma baltica (9\%) (Fig. 6). In the reference area Marenzelleria viridis dominated with $27 \%$, followed by Bathyporeia pilosa (14.6\%) and Eteone longa (7\%).

Similarities among grab sample data are presented in the MDS plots in Fig. 7. Stations in the disposal area showed clear clusters in all surveys. The stress of all presentations is low, and therefore the plots give reliable pictures of the situation. The distinction between the data of the disposal and the reference stations was clearer in April 1997 than in August and October 1996. Stations V and VI, situated in the shallow water area, showed a high similarity with one another and with the disposal area in August. In April, the data of stations V and VI were similar to those of the reference stations. In August station VII showed a very low similarity to the disposal area, which was due to the presence of Mytilus edulis in that month. The same could be seen at station VIII in October 1996.

Similarity percentage (SIMPER) analysis of both groups showed an average dissimilarity of $63.4 \%$ in August 1996, 83.5\% in October 1996 and 74.9\% in April 1997. These data are supported by the species listed in Table 3.

Heteromastus filiformis showed a higher than average abundance at the disposal site in all surveys (Table 3). In the reference area, species such as Petricola pholadiformis, Polydora caeca, Bathyporeia pilosa, Marenzelleria viridis and Nephtys caeca were more abundant, yet their respective dominance differed during the survey. To 


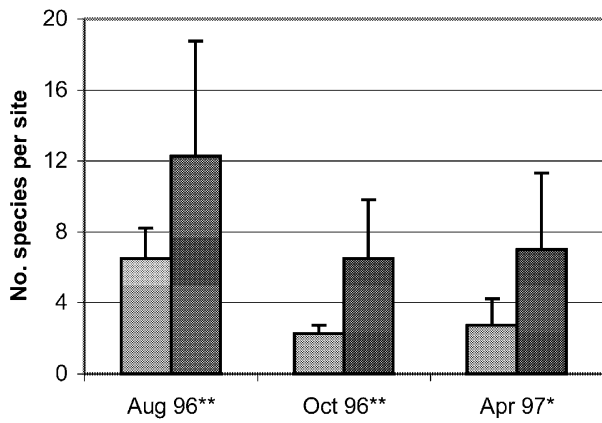

口Disposal area $\square$ Reference area

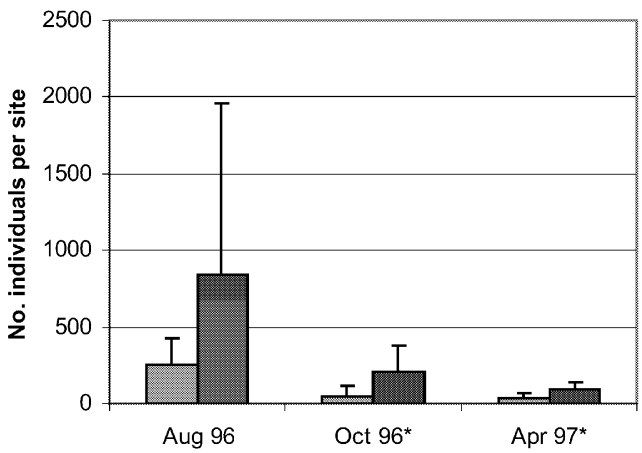

口Disposal area

QReference area

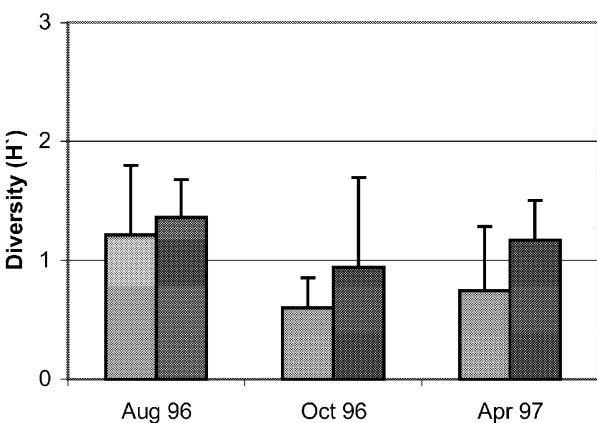

$\square$ Disposal area

घReference area

Fig. 5 Numbers of species and individuals per site, and diversity $\left(H^{\prime}\right)$ for the three surveys (grab samples; mean, with standard deviation indicated by black line; asterisks indicate significance according to Mann-Whitney U-test: ${ }^{*} P<0.1,{ }^{*} P<<0.05$, $\left.* * * P<0.01\right)$

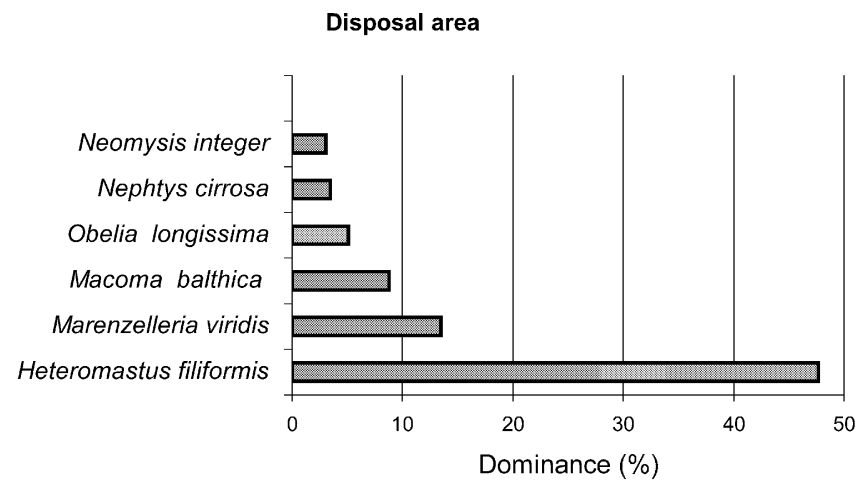

Reference area

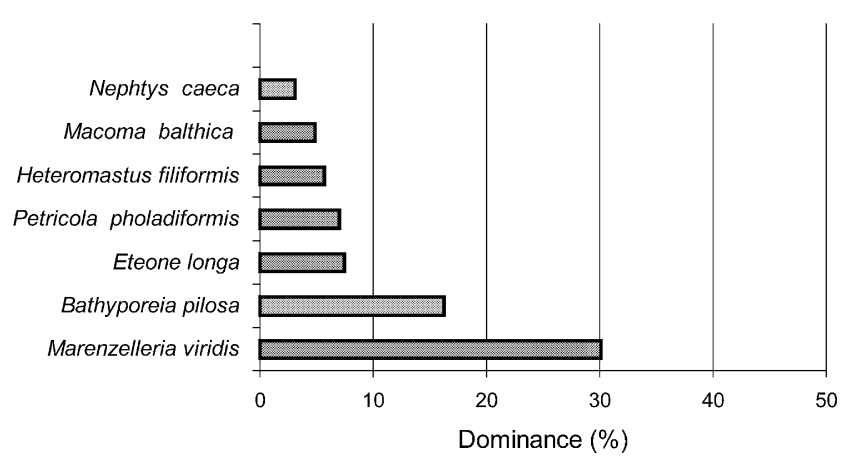

Fig. 6 Numerical dominance of species (\%) in the disposal and the reference areas (grab sample data, all surveys, species with more than $5 \%$ dominance only)

minimise seasonal influences, the average abundances from all surveys $(n=12)$ are given in Table 4.

Crustaceans such as Balanus crenatus and Bathyporeia pilosa, the polychaete Nephtys caeca and the bivalve Petricola pholadiformis showed significantly lower abundances in the disposal area compared to the reference area. The reduction in the abundances of mobile species such as Neomysis integer, Carcinus maenas or Crangon crangon was not significant (see below). Some species that occurred with low abundances in the reference area (Metridium senile, Sargartia troglodytes, Corophium volutator, Harmothoe spp., Pygospio elegans, Tharyx kil-
Table 3 Average abundances of species contributing with high percentages to the dissimilarity between the disposal and reference areas (total dissimilarity in \%, SIMPER analysis, fourth-root transformed grabsample data, $n=4$ )

\begin{tabular}{|c|c|c|c|c|}
\hline \multirow[t]{2}{*}{ Survey } & \multirow[t]{2}{*}{ Taxon } & \multicolumn{2}{|c|}{ Average abundance (Individuals $/ \mathrm{m}^{2}$ ) } & \multirow[t]{2}{*}{ Contribution (\%) } \\
\hline & & Disposal area & Reference area & \\
\hline \multirow[t]{4}{*}{ August 1996} & Total dissimilarity $63.4 \%$ & & & \\
\hline & Heteromastus filiformis & 126.7 & 34.5 & 12.8 \\
\hline & Polydora caeca & 0.0 & 422.5 & 12.2 \\
\hline & Marenzelleria viridis & 54.3 & 124.5 & 12.1 \\
\hline \multirow[t]{4}{*}{ October 1996} & Total dissimilarity $83.5 \%$ & & & \\
\hline & Heteromastus filiformis & 41.5 & 8.3 & 11.6 \\
\hline & Petricola pholadiformis & 0.0 & 53.3 & 6.9 \\
\hline & Bathyporeia pilosa & 0.0 & 100.0 & 6.7 \\
\hline \multirow[t]{4}{*}{ April 1997} & Total dissimilarity $74.9 \%$ & & & \\
\hline & Nepthys caeca & 0.8 & 23.3 & 10.7 \\
\hline & Heteromastus filiformis & 25.8 & 13.25 & 9.9 \\
\hline & Nereis virens & 4.0 & 0.0 & 8.6 \\
\hline
\end{tabular}



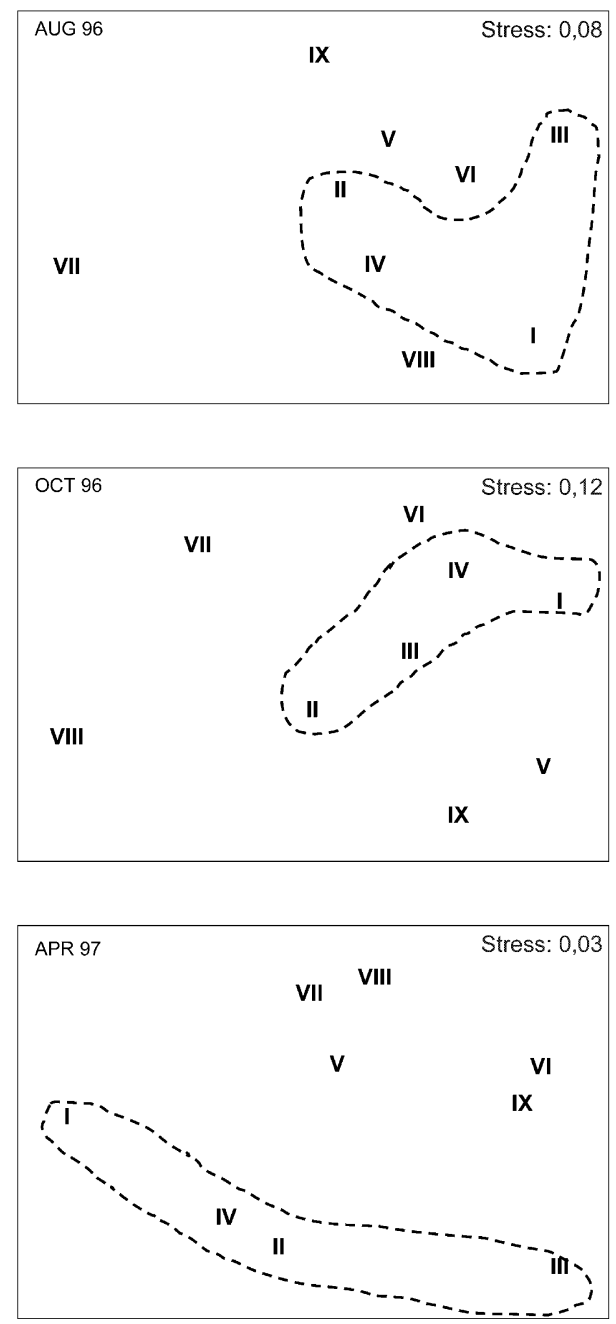

Fig. 7 Results of multidimensional scaling of the endobenthic data (grab samples); MDS plots for the three surveys from August 1996April 1997. Stations of the disposal area surrounded by dotted line (Bray-Curtis similarity, fourth-root transformed data)

lariensis and Phyllodoce mucosa) were missing at the disposal sites. The structurally important species Lanice conchilega was not present; adult Mytilus edulis were rare in the disposal area (Table 4).

Epibenthic macrofauna (dredge-sample data)

A total of 53 benthic species and 12 fish species were caught in dredge samples: 38 species in the disposal area, and 62 species in the reference area. In Table 5, the number of species and individuals as well as community indices are given for the disposal and reference areas. The average species number per site was significantly lower in the dumping area (11.5 species) than in the reference area (17.0 species, $P<0.01)$. The highest species number per site was 29, recorded at station VII in April 1997. The number of individuals was lower in the dumping area, with an average of 282 individuals per station compared to 671 individuals at the reference sites $(P<0.05$, Mann-
Table 4 Densities of the 15 most abundant species from grab samples in the disposal $(n=12)$ and reference $(n=12)$ areas (endobenthic and sessile epibenthic species only)

\begin{tabular}{|c|c|c|c|c|c|}
\hline \multirow[t]{2}{*}{ Taxon } & \multirow[t]{2}{*}{$\begin{array}{l}\text { Signif- } \\
\text { icance }^{a}\end{array}$} & \multicolumn{2}{|c|}{$\begin{array}{l}\text { Disposal area } \\
\text { (stations I-IV) }\end{array}$} & \multicolumn{2}{|c|}{$\begin{array}{l}\text { Reference area } \\
\text { (stations VI-IX) }\end{array}$} \\
\hline & & Mean & $\pm \mathrm{SD}$ & Mean & $\pm \mathrm{SD}$ \\
\hline Metridium senile & & 0.0 & 0.0 & 6.7 & 14.9 \\
\hline Obelia longissima & & 7.0 & 21.2 & 1.9 & 6.4 \\
\hline $\begin{array}{l}\text { Corophium } \\
\text { volutator }\end{array}$ & & 0.0 & 0.0 & 6.5 & 20.7 \\
\hline Bathyporeia pilosa & $*$ & 0.0 & 0.0 & 38.6 & 107.5 \\
\hline Balanus crenatus & $*$ & 0.0 & 0.0 & 33.8 & 111.9 \\
\hline Eteone longa & & 0.3 & 0.8 & 15.9 & 33.6 \\
\hline $\begin{array}{l}\text { Marenzelleria } \\
\text { viridis }\end{array}$ & & 18.3 & 32.9 & 43.7 & 108.3 \\
\hline Nereis virens & & 1.3 & 2.8 & 5.7 & 14.0 \\
\hline $\begin{array}{l}\text { Heteromastus fili- } \\
\text { formis }\end{array}$ & & 64.7 & 118.7 & 18.7 & 24.0 \\
\hline Tharyx killariensis & & 0.0 & 0.0 & 3.1 & 7.5 \\
\hline Nephtys caeca & $* * *$ & 2.5 & 7.4 & 11.0 & 15.6 \\
\hline Phyllodoce тисова & & 0.0 & 0.0 & 1.9 & 5.5 \\
\hline Lanice conchilega & & 0.0 & 0.0 & 1.4 & 4.7 \\
\hline Macoma balthica & & 12.0 & 17.1 & 12.2 & 16.1 \\
\hline Mytilus edulis & & 1.1 & 2.8 & 50.8 & 92.0 \\
\hline $\begin{array}{l}\text { Petricola pholadi- } \\
\text { formis }\end{array}$ & $*$ & 0.0 & 0.0 & 20.8 & 41.3 \\
\hline
\end{tabular}

${ }^{\mathrm{a}}$ Mann-Whitney test; $* P<0.1, * * P<0.05, * * * P<0.01$

Table 5 Numbers of species and individuals (mean \pm SD), and community indices (mean) from dredge samples in the disposal $(n=12)$ and reference $(n=12)$ areas (endobenthic and sessile epibenthic species only)

\begin{tabular}{|c|c|c|c|c|c|}
\hline & \multirow[t]{2}{*}{$\begin{array}{l}\text { Signif- } \\
\text { icance }^{\mathrm{a}}\end{array}$} & \multicolumn{2}{|c|}{$\begin{array}{l}\text { Disposal area } \\
\text { (stations I-IV) }\end{array}$} & \multicolumn{2}{|c|}{$\begin{array}{l}\text { Reference area } \\
\text { (stations VI-IX) }\end{array}$} \\
\hline & & Mean & $\pm \mathrm{SD}$ & Mean & $\pm \mathrm{SD}$ \\
\hline \multicolumn{6}{|l|}{ Species per site } \\
\hline Total & $* * *$ & 11.5 & 3.1 & 17.0 & 7.3 \\
\hline Cnidaria & $* *$ & 2.2 & 1.3 & 3.5 & 1.6 \\
\hline Crustacea & & 4.7 & 1.8 & 5.3 & 2.2 \\
\hline Polychaeta & & 0.5 & 0.9 & 1.8 & 2.6 \\
\hline Mollusca & $* * *$ & 0.8 & 0.7 & 2.3 & 1.3 \\
\hline \multicolumn{6}{|l|}{ Individuals per site } \\
\hline Total & $* *$ & 282.4 & 388.6 & 671.3 & 734.0 \\
\hline Crustacea & $* *$ & 159.2 & 188.0 & 319.6 & 385.2 \\
\hline Polychaeta & & 0.7 & 1.4 & 27.4 & 56.9 \\
\hline Mollusca & ** & 87.6 & 210.6 & 186.2 & 418.4 \\
\hline Echinodermata & & 0.6 & 1.0 & 66.5 & 116.7 \\
\hline \multicolumn{6}{|l|}{ Community indices } \\
\hline Diversity & & 1.5 & - & 1.4 & - \\
\hline Species richness & & 2.3 & - & 2.8 & - \\
\hline Evenness & & 0.6 & - & 0.2 & - \\
\hline
\end{tabular}

${ }^{\text {a }}$ Mann-Whitney test; $* P<0.1, * * P<0.05, * * * P<0.01$

Whitney). There was almost no difference in diversity between both areas, although species richness was higher in the reference area (2.8) than in the disposal area (2.3) (Table 5).

Comparing both areas at a higher taxonomic level, there were significantly lower species numbers of cnidarians and molluscs at the dumping sites (Table 5). The abundance of crustaceans and molluscs at the dumping sites was significantly lower than in the reference area. 

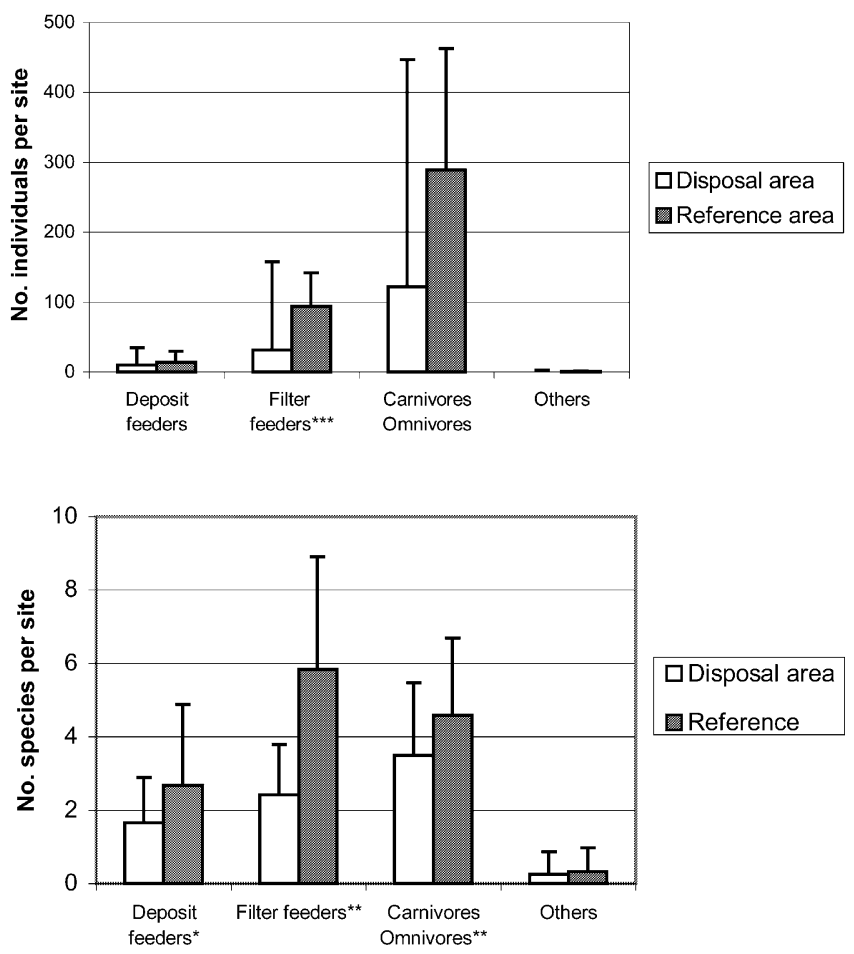

Fig. 8 Number of individuals and species of invertebrates with different feeding modes from the disposal and reference areas (all surveys, epibenthic species only, standard deviation indicated by black line, asterisks indicate significance according to MannWhitney U-test: $* P<0.1, * * P<0.05, * * * P<0.01)$

The cnideria was the only group with higher numbers of individuals in the disposal area, although filter feeding, sessile epifauna are supposed to be sensitive to all changes to the sediment surface (Newell et al. 1998).

Epibenthic samples from the reference area showed higher numbers of species and individuals for all feeding guilds (Fig. 8). There were significantly higher numbers of species (5.8 species per site) in the reference area than in the disposal area (2.2 species per site). Filter feeders and carnivore/omnivore species showed significantly higher numbers of individuals in the reference area compared to the disposal area. In other groups (e.g. deposit feeders), smaller differences between the reference and disposal areas were recorded, with high variance in the data and therefore no statistical significance (Fig. 8).

The MDS plots of the similarity matrix of the dredge trawls from August 1996-April 1997 are shown in Fig. 9. The disposal sites (stations I-IV) showed clear clusters. Stations V and VI (both in shallower water) were always close to each other, indicating the influence of water depth on the benthic community. The two data groups showed an average dissimilarity of $60.2 \%$ in August 1996, 44.2\% in October 1996, and 64.2\% in April 1997 (SIMPER; Table 6). The species with the most influence on this dissimilarity differed during the surveys; seasonal changes were important as seen in the grab data. Vagile crustaceans such as Praunus flexuosus and Schistomysis kervillei were found with higher abundances in the dis-
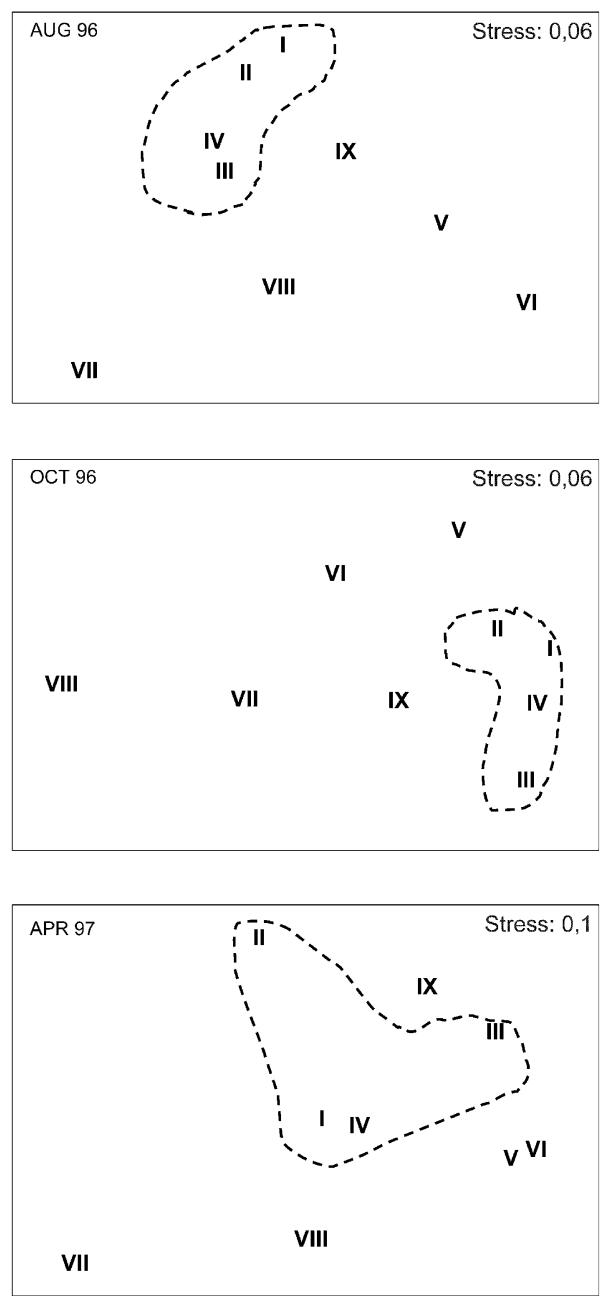

Fig. 9 Results of multidimensional scaling of the epibenthic data (dredge samples); MDS plots for three surveys from August 1996April 1997. Stations of the disposal area surrounded by dotted line (Bray-Curtis similarity, presence-absence transformed data)

posal area. In the reference area, species such as Neomysis integer, Asterias rubens and Crangon crangon dominated (Table 6).

All surveys taken together, we recorded lower average abundances in the disposal area for species such as Crangon crangon, Metridium senile, Asterias rubens and Mytilus edulis. Praunus flexuosus and Gammarus salinus were more abundant in the disposal area. The average abundances of selected species for all surveys are given in Table 7. At the species level there was a significant reduction in the abundances of species such as Metridium senile, Sargartia troglodytes, Mytilus edulis, Lanice conchilega and the associated macrofauna, e.g. Asterias rubens. Others, such as Hartlaubella gelatinosa, Sertularia cupressina, Nereis succinea and Hydrobia ulvae showed declines in abundances that were not statistically significant. The species Urticina eques, Nymphon spp., Harmothoe imbricata, Mya arenaria, Petricola pholadiformis and Ensis directus were not present in the disposal area but could be found in the reference area. Hard-sub- 
Table 6 Average abundances of species contributing with high percentages to the dissimilarity between the disposal and the reference areas (SIMPER analysis, fourth-root transformed data of dredge samples, $n=4$ sites)

Table 7 Densities of 15 species from dredge samples in the disposal $(n=12)$ and reference $(n=12)$ areas

\begin{tabular}{|c|c|c|c|c|}
\hline \multirow[t]{2}{*}{ Survey } & \multirow[t]{2}{*}{ Taxon } & \multicolumn{2}{|c|}{ Average abundance (Individuals $/ \mathrm{m}^{2}$ ) } & \multirow[t]{2}{*}{ Contribution (\%) } \\
\hline & & Disposal area & Reference area & \\
\hline \multirow[t]{4}{*}{ August 1996} & Total dissimilarity $60.2 \%$ & & & \\
\hline & Praunus flexuosus & 14.5 & 4.8 & 6.9 \\
\hline & Schistomysis kervillei & 8.3 & 4.3 & 6.9 \\
\hline & Asterias rubens & 0.3 & 152.8 & 6.1 \\
\hline \multirow[t]{4}{*}{ October 1996} & Total dissimilarity $44.2 \%$ & & & \\
\hline & Balanus crenatus & 12.5 & 11.5 & 9.2 \\
\hline & Mytilus edulis & 0.0 & 15.5 & 7.3 \\
\hline & Gammarus salinus & 42.5 & 4.5 & 6.3 \\
\hline \multirow[t]{4}{*}{ April 1997} & Total dissimilarity $64.2 \%$ & & & \\
\hline & Crangon crangon & 1.8 & 21.8 & 6.6 \\
\hline & Mytilus edulis & 3.8 & 1.5 & 6.4 \\
\hline & Metridium senile & 0.5 & 20.0 & 5.0 \\
\hline
\end{tabular}

\begin{tabular}{|c|c|c|c|c|c|}
\hline \multirow[t]{2}{*}{ Taxon } & \multirow[t]{2}{*}{ Significance $^{\mathrm{a}}$} & \multicolumn{2}{|c|}{$\begin{array}{l}\text { Disposal area } \\
\text { (stations I-IV) }\end{array}$} & \multicolumn{2}{|c|}{$\begin{array}{l}\text { Reference area } \\
\text { (stations VI-IX) }\end{array}$} \\
\hline & & Mean & $\pm \mathrm{SD}$ & Mean & $\pm \mathrm{SD}$ \\
\hline Metridium senile & * & 6.3 & 9.8 & 38.2 & 68.4 \\
\hline Sagartia troglodytes & $* *$ & 0.0 & 0.0 & 4.6 & 6.4 \\
\hline Obelia longissima & & 23.5 & 37.0 & 6.5 & 11.0 \\
\hline Sertularia cupressina & & 0.2 & 0.4 & 1.3 & 2.1 \\
\hline Crangon crangon & & 114.8 & 170.3 & 283.8 & 388.6 \\
\hline Gammarus salinus & & 14.6 & 31.0 & 2.0 & 2.8 \\
\hline Gammarus locusta & & 3.9 & 7.9 & 1.6 & 3.4 \\
\hline Carcinus maenas & & 7.8 & 12.9 & 17.5 & 26.4 \\
\hline Praunus flexuosus & & 4.9 & 8.7 & 2.3 & 3.7 \\
\hline Nereis succinea & & 0.0 & 0.0 & 7.2 & 22.0 \\
\hline Lanice conchilega & * & 0.0 & 0.0 & 11.3 & 34.9 \\
\hline Harmothoe imbricata & & 0.0 & 0.0 & 1.5 & 4.4 \\
\hline Mytilus edulis & $* *$ & 0.1 & 0.3 & 148.4 & 417.2 \\
\hline Petricola pholadiformis & & 0.0 & 0.0 & 0.8 & 1.9 \\
\hline Asterias rubens & ** & 0.6 & 1.0 & 66.5 & 116.7 \\
\hline
\end{tabular}

${ }^{a}$ Mann-Whitney test, $* P<0.1, * * P<0.05, * * * P<0.01$ strate species such as Obelia spp. and associated macrofauna such as Gammarus spp. and juvenile Mytilus edulis occurred more abundantly in the disposal area.

\section{Discussion}

The data presented in this study focus on physical effects of open water disposal on macrobenthic invertebrates that are known to indicate changes in sediments and morphology (Rachor 1982). However, a disposal of sediments can affect pelagic communities as well (Saila et al. 1972; Hagendorff et al. 1996; Kofod 1997).

There are two main physical impacts of sediment disposal on benthic communities (Krost 1996). First, there is a direct physical disturbance resulting from the formation of a covering layer in the centre of the disposal area from the discharged sediment. Maurer et al. (1986) found vertical migration and increased mortality depending on the persistence of the covering layer, its depth and the type of discharged material. Second, increased turbidity can lead to changes in metabolic rates of filter feeders and reduced larval recruitment and growth (Rosenberg 1977a, 1977b; Davis and Hidu 1988). The impact depends on the amount of discharged sediment, disposal time, water depth, currents, particle size, and other abiotic parameters (van Dolah et al. 1984). Figure 10 summarises the main effects of sediment disposal in marine or estuarine waters, as described by various authors (Krost 1996; Essink 1996). Currents influence the drift of suspended material, resuspension and sediment advection after the discharge. Therefore the area of impact may not correspond to the disposal area. Exact information about the position and physical impact of the discharge must be investigated before its effects on the benthic fauna can be studied adequately.

\section{Sediments}

The computer-generated model by Zanke (1998) predicted that the impact area (Fig. 2) would have a disposal layer of at least $10 \mathrm{~mm}$ for a period of more than 25 days. The centre of the dumping area was expected to have covering layers of $65 \mathrm{~mm}$ during the dumping period and for a short time (several hours) afterwards (Zanke 1998). The results of the sediment analysis confirmed the prediction of the computer model as to sediment composition; the higher proportion of silt in the disposal area was 


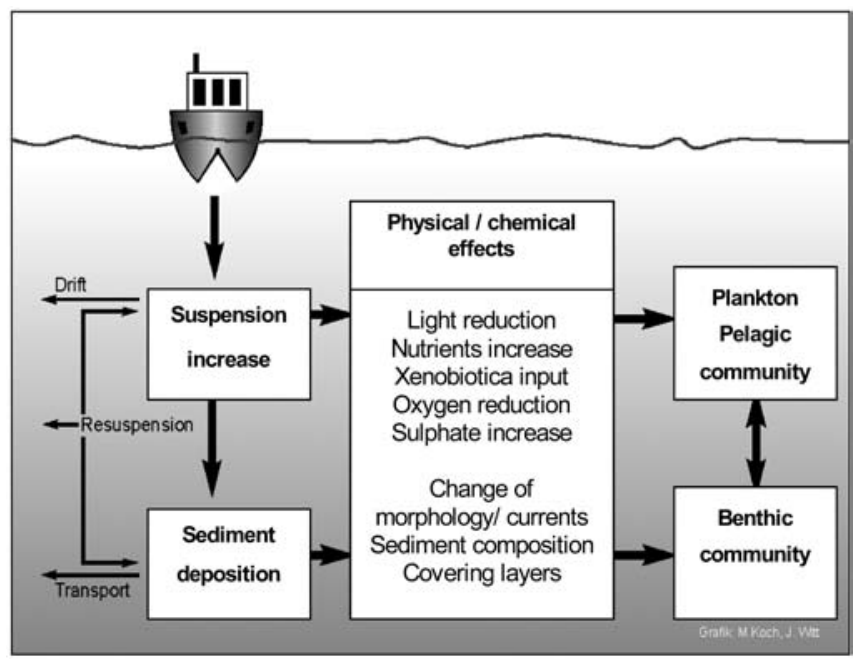

Fig. 10 Diagram summarising potential effects of sediment disposal in open waters

caused by the disposal of muddy harbour sludge with a high percentage of organic matter. The silt fraction, however, was washed into the sediment to a depth of up to $20 \mathrm{~cm}$ and did not necessarily form a surface layer. The high variation in the silt proportion at the disposal sites was probably caused by the lateral advection of sediments by the tidal currents. A major part of the sediment discharge was eroded immediately after dumping and carried away by the strong currents. Most of it was expected to stay in the area of the Wurster Arm as a thin layer of a few millimetres, according to the computer model (Zanke 1998). The present study was not intended to verify the prediction, but it was obvious that at least part of the deposit was washed into the sediment, changing its characteristics by silt enrichment. Other investigations found a complete eroding of the discharge layer within hours after dumping (Rumohr 1996; Nehring and Leuchs 1997).

\section{Endobenthic macrofauna}

The presented data indicate a clear faunal impoverishment in the disposal area. The endobenthic fauna showed more marked responses in relation to abundance and diversity than the epibenthic fauna. This is due to the higher proportion of sessile and hemi-sessile species in the endobenthic community compared to the more vagile species in the epibenthic assemblage.

At the disposal site, numbers of endobenthic and sessile epibenthic invertebrate species were reduced to about $50 \%$. Faunal differences between the disposal site and the reference area were correlated with changes in the sediment composition. The disposal sites had a higher proportion of silt and mud, which influenced species composition. The results showed significant differences at the community level, higher taxonomic levels and ultimately, at the species level, which is the most important level for understanding ecological interactions (Hall 1994).
The comparison of the dominance structures showed that the impact area was dominated by Heteromastus filiformis, Marenzelleria viridis and Macoma balthica. The polychaete $H$. filiformis prefers mud with a high content of organic matter as a substrate, and the deposit feeder $M$. balthica also may be affected by the nutrient input at the disposal site. Both species appear to respond opportunistically to the disposal of muddy material and nutrient enrichment. Similarly, Tesch and Witt (1998) described an opportunistic reaction of M. balthica and $H$. filiformis with highly increased abundances a few months after a disposal of dredged clay in a neighbouring area. Oligochaetes and some polychaetes (Capitella sp., Scolelepis sp.) showed high abundances in the epicentre of a sewage sludge disposal in Scotland (Pearson et al. 1986).

Opportunistic species are typical members of the estuarine community of muddy sediments which are subject to frequent disturbances (Newell et al. 1998). These communities are well-adapted to rapid recolonisation and are characterised by large populations of a restricted variety of species. This might be true of most areas of the Weser channel system, but in this case it was the disposal that transformed sand and stone surfaces into bottoms of fine silt and mud, even in the presence of strong currents. The occurrence of opportunistic species such as $H$. filiformis after the disposal indicates a strong impact of the disposal on sandy habitats.

Marenzelleria viridis was first recorded in the Weser estuary in 1986 and has become dominant in most brackish sediments since then. Although its abundance in the reference area is twice that of the disposal area, this species does not provide a reliable indicator of disposal effects because of its variability in abundance and progressive invasion of all mesohaline sediments (Tesch and Witt 1998).

Crustaceans were reduced in species number and abundance within the disposal area. The strong effect on Bathyporeia pilosa, which prefers sandy sediments, also seems to be caused by the change in sediment composition after the disposal. Corophium volutator was missing in the impact area, although this species is attracted to muddy sediments. This may be due to the lack of a stable sediment surface in the disposal area and the absence of benthic algae such as diatoms as a food resource.

The low abundance of endobenthic polychaetes such as Tharyx killariensis, Polydora caeca, Phyllodoce mucosa and Nephtys caeca in the dumping area was probably due to reduced oxygen and to an input of sulfide from the discharge, which may stress these species (Pearson and Rosenberg 1978). The role of these chemical stress factors for specific species needs to be investigated further. The mobile Nephtys spp. survived covering layers of several decimetres in laboratory tests (Essink 1996). They are considered "equilibrium species" that indicate a high succession level of the community (Pearson and Rosenberg 1978). Eteone longa, a more fragile species, was probably not robust enough to survive the disposal and therefore disappeared completely from the affected area. 
Table 8 Effects of sediment disposal on selected species, and consequences for the community. Abundance in the disposal area compared to the reference area: $\uparrow$ higher abundance, $\downarrow$ lower abundance, $\downarrow$ no response, - absent from data set

\begin{tabular}{|c|c|c|c|c|c|}
\hline Taxon & $\begin{array}{l}\text { Aug. } \\
1996\end{array}$ & $\begin{array}{l}\text { Oct. } \\
1996\end{array}$ & $\begin{array}{l}\text { April } \\
1997\end{array}$ & Effects on species & Consequences \\
\hline \multicolumn{6}{|l|}{ Dredge sample data } \\
\hline Mytilus edulis & $\downarrow$ & $\downarrow$ & $\downarrow$ & $\begin{array}{l}\text { Reduction, absent in disposal area; } \\
\text { sensitive to sediment cover, turbidity }\end{array}$ & Loss of habitats and diversity (associated fauna) \\
\hline Lanice conchilega & - & $\downarrow$ & $\downarrow$ & $\begin{array}{l}\text { Reduction, partly absent in disposal area; } \\
\text { sensitive to sediment cover }\end{array}$ & Loss of habitats and diversity (associated fauna) \\
\hline Metridium senile & $\bullet$ & $\downarrow$ & $\downarrow$ & $\begin{array}{l}\text { Significant reduction; sensitive to sediment } \\
\text { cover }\end{array}$ & Reduction of diversity, loss of age structure \\
\hline Urticina eques & - & $\downarrow$ & $\downarrow$ & Reduction; sensitive to sediment cover & Reduction of diversity, loss of age structure \\
\hline Sertularia cupressina & $\downarrow$ & 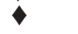 & $\downarrow$ & Reduction; sensitive to sediment cover & Reduction of diversity, endangered species \\
\hline Balanus crenatus & $\bullet$ & $\downarrow$ & $\downarrow$ & $\begin{array}{l}\text { Reduction, partly absent; sensitive } \\
\text { to sediment cover }\end{array}$ & Indicates sensitive hard-bottom substrates \\
\hline Asterias rubens & $\downarrow$ & $\downarrow$ & $\downarrow$ & $\begin{array}{l}\text { Significant reduction; associated } \\
\text { with Mytilus }\end{array}$ & Indicates loss of prey (Mytilus) \\
\hline Gammarus spp. & $\uparrow$ & $\bullet$ & $\downarrow$ & $\begin{array}{l}\text { Associated with Mytilus and Obelia, } \\
\text { therefore unspecified }\end{array}$ & - \\
\hline $\begin{array}{l}\text { Petricola pholadi- } \\
\text { formis }\end{array}$ & $\downarrow$ & $\downarrow$ & - & $\begin{array}{l}\text { Complete disappearance under sediment } \\
\text { cover }\end{array}$ & $\begin{array}{l}\text { Indicator of sediment deposits in special locations } \\
\text { (peat, clay) }\end{array}$ \\
\hline Bathyporeia pilosa & $\downarrow$ & $\downarrow$ & - & Reduction, partly absent from disposal area & Indicator of sandy habitats, avoids silt sediments \\
\hline Eteone longa & $\downarrow$ & - & $\downarrow$ & Reduction, partly absent from disposal area & Abundance generally too low for indication \\
\hline Macoma balthica & $\uparrow$ & $\uparrow$ & $\downarrow$ & Robust species & $\begin{array}{l}\text { Indicates nutrient increase; after a certain period } \\
\text { opportunistic }\end{array}$ \\
\hline $\begin{array}{l}\text { Heteromastus } \\
\text { filiformis }\end{array}$ & $\uparrow$ & $\uparrow$ & $\uparrow$ & Increase of abundance, opportunistic & $\begin{array}{l}\text { Indicator of silt and nutrient input, sediment change } \\
\text { towards finer grain size }\end{array}$ \\
\hline
\end{tabular}

The bivalve Petricola pholadiformis also appears to be sensitive to disposal. Unlike many others, this sessile species cannot move to overcome sedimentation and to ensure steady contact with the water column for respiration and filtration. Staying covered by sediment layers for more than a few hours is most likely lethal for Petricola pholadiformis (Essink 1996). However, its patchy distribution (mostly in clay sediments or peat) reduces the value of this clam as an indicator.

\section{Epibenthic macrofauna}

Differences in species composition between the disposal and reference areas were due to the more diverse and abundant assemblage of cnidarians, molluscs and polychaetes in the reference area. Important species for the diversity of the community such as the mussel Mytilus edulis and the polychaete Lanice conchilega were absent from the disposal area, as were the associated macrofauna. This supports the results of Widdows et al. (1979) who demonstrated a sensitive response (lowered metabolic rates and morphological deformation) of Mytilus edulis to increased turbidity. Essink (1996) reported that filtration in Mytilus edulis stops when the mussel is covered by only a few millimetres of sediment. The feeding behaviour of benthic invertebrates is responsible for their individual sensitivity to sediment interference (Pearson and Rosenberg 1978; van Dolah et al. 1984; Essink 1995). The polychaete Lanice conchilega is a sessile, non-se- lective filter feeder which shows a strong decline when covered by disposal sediments. Both species can be considered indicators due to their sensitive response to disposal activities and their slow recovery.

Asterias rubens, a predator of mussels, is dependent on Mytilus edulis and therefore was less abundant in the disposal area. Metridium senile and Sagartia troglodytes, both filter feeders on hard substrate, were less abundant in the impact area and seemed to be sensitive to disposal effects. Although hard substrates were available, Balanus crenatus was less abundant in the disposal area. The effects of muddy discharge on this filter feeding species were more severe than those on other filter feeders such as Obelia spp. which were more abundant in the dump area. This might be due to the differences in the distance between the feeding organs and the sediment surface. Balanids may stop filtration after silt layers of a few millimetres have been discharged, whereas flexible stems of Obelia spp. rise up to $20 \mathrm{~cm}$ above the bottom. On the other hand, Sertularia cupressina, which has a similar morphology, was strongly reduced in abundance. Obelia longissima was the only filter feeder that survived in the disposal areas without reduction in abundance. Postlarval Mytilus edulis were very often found attached to Obelia spp. so that they also occurred with higher abundance in the disposal area. This was similar to other associated species such as Gammarus salinus and Gammarus locusta, which showed even higher abundances in the disposal area. Other associated macrofauna such as Aeolydia pallida and Nymphon spp. appeared to be sensitive to 
disposal and consequently avoided affected areas. In summary, macrofaunal assemblages of hydrozoans and their associated fauna were not completely destroyed by the disposal, yet their diversity was much reduced. Epibenthic polychaetes, which are active on the sediment surface, seemed to be more sensitive to disposal than others. Harmothoe spp., Nereis spp., Eteone longa and Lepidonotus squamatus were less abundant in the disposal area but this was not statistically significant. Epibenthic mobile crustaceans such as Neomysis integer, Schistomysis kervillei and Praunus flexuosus occurred in higher abundances in the disposal area and may have profited from nutrient input or increased access to their common meiofaunal prey, which often respond opportunistically to disturbances. The observed responses of selected endobenthic and epibenthic species to disposal and the consequences for the community are listed in Table 8 .

\section{Conclusions}

The effects of sediment discharge on benthic communities in dynamic habitats such as estuarine channels have not been well studied though they are important for decision makers. An adequate assessment faces serious problems because it is often difficult to find a reliable reference area within the estuarine gradient, and because the conditions in such habitats are highly variable over time and space. For the present study, a morphodynamic computer model was helpful for determining the position and extent of the impact area. The predictions of the computation could be confirmed by the biological data. The study showed that even in dynamic habitats such as estuarine channels, severe effects of sediment disposals can be measured and assessed by biological monitoring. Benthic macrofaunal species were affected differently according to their specific feeding behaviour, mobility or morphology. The effects can be described at the community level, at higher taxonomic levels and at the species level using univariate and multivariate methods. The values of species as indicators for predicting or reflecting specific effects were discussed. Although the different effects can be explained by the biology of the species, specific laboratory experiments are needed for more detailed information. An understanding of species' strategies for overcoming impacts such as sediment covering is still sparse (see Grall and Glemarec 1997).

For a complete impact assessment, the recovery of the affected areas has to be investigated. In order to achieve this, an additional sampling set was done in August 1999, about 26 months after the disposals were stopped. The results of that study will be presented in a forthcoming publication. Species such as Mytilus edulis and Lanice conchilega which provide habitats for associated macrofaunal species are important for the community structure, its integrity and species richness. Their sensitivity to physical disposal effects may lead to severe consequences for the community. In addition to these structure-providing species, the importance of epibenthic assemblages on hard-bottom substrates should be emphasised. Anthozoans such as Metridium senile represented a well-developed epibenthic community of mature individuals. They reacted sensitively to the discharge and indicated the strong impact of sediment disposals on hard-bottom assemblages. Finding more benthic indicators for the precise determination of the different anthropogenic impacts on the benthic community can reduce monitoring and analysis efforts, and remains a scientific target in the future.

Acknowledgements We thank the harbour authority of Bremen (Bremenports $\mathrm{GmbH}$, formerly Hansestadt Bremisches Hafenamt Bremerhaven), in particular U. von Bargen and Dr U. Burghardi for supporting this paper and for the release of data. Many thanks are due to the crew of the Bremenports vessel Hol Deep and to the KÜFOG team for being a great help during field and laboratory work.

\section{References}

Barnes RSK (1994) The brackish-water fauna of northwestern Europe. Cambridge University Press, Cambridge

BFG (Bundesanstalt für Gewässerkunde) (1992) Handlungsanweisungen-Anwendung der Baggergutrichtlinien der OsloHelsinki-Kommission in der Wasser- und Schifffahrtsverwaltung des Bundes (HABAK-WSV) BFG, Koblenz. BFG Ber 700, Koblenz

BFG (Bundesanstalt für Gewässerkunde) (1999) Handlungsanweisung für den Umgang mit Baggergut im KüstenbereichHABAK. BFG Ber 1100, Koblenz

Boesch DF (1977) Application of numerical classification in ecological investigations of water pollution. Virginia Inst Mar Sci, Spec Sci Rep 77

Buchanan JB (1984) Sediment analysis. In: Holme NA, McIntyre $\mathrm{AD}$ (eds) Methods for the study of marine benthos. IBP Handbook 16. Blackwell, Oxford

Clarke KR, Warwick RM (1994) Change in marine communities: an approach to statistical analysis and interpretation. Plymouth Marine Laboratory, Plymouth, UK

Clarke KR, Gorley RN (2001) PIMER v. 5, user manual. Plymouth Marine Laboratory, Plymouth, UK

Davis HC, Hidu H (1988) Effects of turbidity-producing substances in sea water on eggs and larvae of three genera of bivalve molluscs. Veliger 11:316-324

Essink K (1995) Ecological effects of dredging and dumping of dredge spoil. Waddensea Newsl 1:9-14

Essink K (1996) Die Auswirkungen von Baggergutablagerungen auf das Makrozoobenthos-Eine Übersicht der niederländischen Untersuchungen. In: BFG (ed) Baggern und Verklappen im Küstenbereich. BFG Mitt 11:12-17

Essink K, Steyfarth FHIM, Mulder HPJ, de Jonge VN, van Heuvel T, van den Bergs J (1992) Effects of dredging activities in the Ems estuary and Dutch Wadden Sea. Neth J Sea Res 20:243246

Grall J, Glemarec M (1997) Using biotic indices to estimate macrobenthic community perturbations in the Bay of Brest. Estuar Coast Shelf Sci 44 (Suppl A):43-53

Hagendorff R, Leuchs H, Nehring S (1996) Eine Literaturübersicht zum Thema Auswirkungen erhöhter Schwebstoffgehalte durch Baggern und Verklappen auf Muscheln. In: BFG (ed) Baggern und Verklappen im Küstenbereich. BFG Mitt 11:7-11

Hall SJ (1994) Physical disturbance and marine benthic communities: life in unconsolidated sediments. Oceanogr Mar Biol Annu Rev 32:179-239

Hartmann-Schröder G (1996) Annelida, Borstenwürmer, Polychaeta. In: Dahl F (ed) Die Tierwelt Deutschlands und der angrenzenden Meeresteile. Fischer, Jena, Germany 
Hayward PJ, Ryland JS (1990) The marine fauna of the British Isles and north-west Europe. Clarendon, Oxford

Kofod M (1997) Abschätzung der Emission umweltrelevanter Stoffe bei der Unterbringung von belastetem Baggergut im subaquatischen Milieu und deren Bewertung. In: BFG (ed) Unterbringung von belastetem Baggergut im aquatischen Milieu. BFG Mitt 6:48-55

Krost P (1996) Eine Literaturübersicht zum Thema "Auswirkungen erhöhter Schwebstoffgehalte durch Baggern und Verklappen auf Muscheln". In: BFG (ed) Baggern und Verklappen im Küstenbereich. BFG-Mitt 11:69-72

Kruskal JB, Wish M (1978) Multidimensional scaling. Sage, Beverly Hills

KÜFOG (1998) Benthoskundliche Untersuchungen zur Einbringung von Baggergut in den Wurster Arm. Zusammenfassende Darstellung der 1.-3. faunistischen Erhebung. HBA, Bremen

Margalef R (1958) Information theory in ecology. Gen Syst 3:3671

Maurer D, Keck RT, Tinsman JC, Leathem WA, Wethe C, Lord C, Church TM (1986) Vertical migration and mortality of marine benthos in dredged material: a synthesis. Int Rev Ges Hydrobiol 71:49-64

McLusky DS (1989) The estuarine ecosystem, 2nd edn. Blackie, Glasgow

Mühlenhardt-Siegel U (1988) Die Weichbodengemeinschaft vor der Elbemündung unter dem Einfluss der Klärschlammverklappung. I. Die saisonale Veränderung von Arten- und Individuenzahl sowie Biomasse unter Berücksichtigung der Sedimentstruktur. Helgol Meeresunters 42:37-65

Mühlenhardt-Siegel U (1990) Die Weichbodengemeinschaft vor der Elbemündungunter dem Einfluss der Klärschlammverklappung. II. Die Gemeinschaftsstruktur im saisonalen Wechsel. Helgol Meeresunters 44:189-217

Nehring S, Leuchs H (1997) Einsatz der Remots-Sedimentprofilkamera zur Dokumentation von Sedimentationsereignissen nach Verklappungen. In: BFG (ed) Baggern und Verklappen im Küstenbereich. BFG Mitt 11:65-68

Newell RC, Seiderer LJ, Hitchcock DR (1998) The impact of dredging works in coastal waters: a review of the sensitivity to disturbance and subsequent recovery of biological resources on the sea bed. Ocean Mar Biol Annu Rev 36:127-78

Pearson TH, Rosenberg R (1978) Macrobenthic succession in relation to organic enrichment and pollution of the environment. Oceanogr Mar Biol Annu Rev 16:229-311
Pearson TH, Ansell AD, Robb L (1986) The benthos of the deeper sediments of the Firth of Clyde, with particular reference to organic enrichment. Proc R Soc Edinb 90B:329-350

PIANC (1998) Management of aquatic disposal of dredged material. Report of Working Group 1 of the Permanent Environment Commission, Brüssel

Pielou EC (1975) Ecological diversity. Wiley, New York

Rachor E (1982) Indikatorarten für Umweltbelastungen im Meer. Dechiana Beih (Bonn) 26:128-137

Remane A (1958) Die Biologie des Brackwassers (Teil I). In: Thienemann A (ed) Die Binnengewässer, Bd XXII. E. Schweitzerbartsche Verlagsbuchhandlung, Leipzig

Rosenberg R (1977a) Effects of dredging operations on estuarine benthic macrofauna. Mar Pollut Bull 8:102-104

Rosenberg R (1977b) Benthic macrofaunal dynamics, production and dispersion in an oxygen-deficient estuary of West Sweden. J Exp Mar Biol Ecol 26:107-133

Rumohr H (1996) Biologische Sukzession nach physikalischen Störungen am Boden der Ostsee. In: BFG (ed) Baggern und Verklappen im Küstenbereich. BFG Mitt 11:69-72

Saila SB, Pratt SD, Polgar TT (1972) Dredge spoil disposal in Rhode Island Sound. University of Rhode Island Marine Technical Report 2, Kingston, RI

Tesch A, Witt J (1998) Ergebnisse des CT III-Monitoringprogramms zur Sandentnahme und Verklappung in der Außenweser. Zusammenfassung und vertiefte Auswertung. WBNL

van Dolah RF, Calder DR, Knott DM (1984) Effects of dredging and open-water disposal on benthic macro-invertebrates in a South Carolina estuary. Estuaries 7:28-37

Wellershaus S (1981) Turbidity maximum and mud shoaling in the Weser Estuary. Arch Hydrobiol 92:161-198

Widdows J, Fieth P, Worall CM (1979) Relationships between seston, available food and feeding activity in the common mussel Mytilus edulis. Mar Biol 50:195-207

Wildish DJ, Thomas MLH (1985) Effects of dredging and dumping on benthos of Saint John Harbour, Canada. Mar Environ Res $15: 45-57$

Woltering K (1997) Grundlagen für ein Baggergutkonzept für Bremerhaven. Vorstudie. HBH, Bremerhaven

Zanke CE (1998) Modelluntersuchungen Baggergutverbringung Wurster Arm. Institut für Wasserbau, TU Darmstadt, Darmstadt 